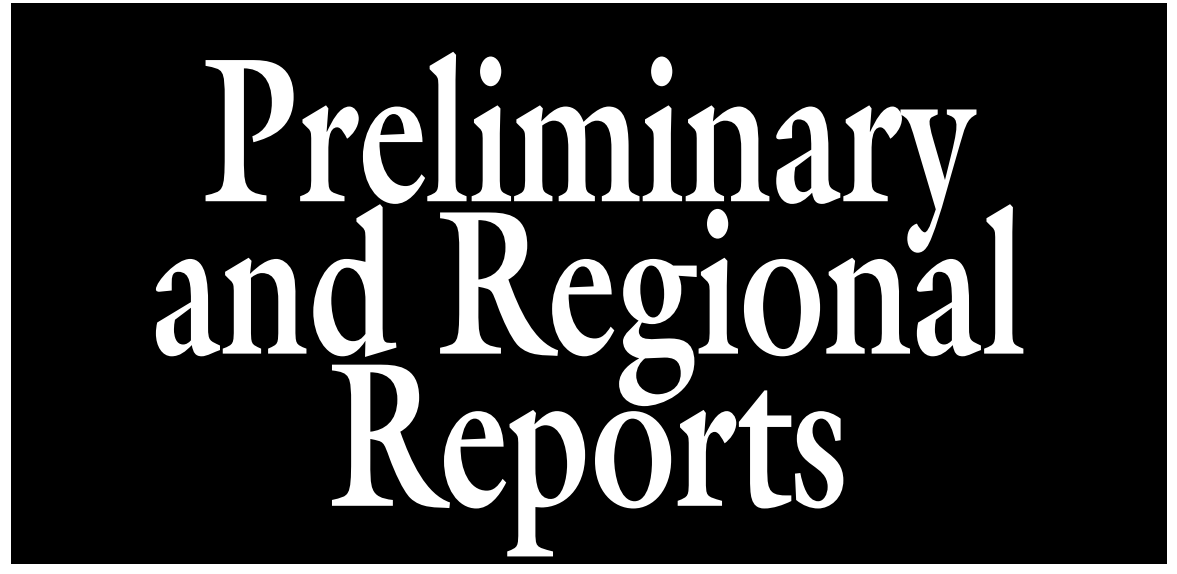

\section{Calcium Fertigation Ineffective at Increasing Fruit Yield and Quality of Muskmelon and Honeydew Melons in California}

\author{
P.R. Johnstone ${ }^{1,4}$, T.K. Hartz ${ }^{2}$, and D.M. May ${ }^{3}$
}

\begin{abstract}
AdDitional INDEX wORDs. fruit firmness, soluble solids, Cucumis melo
SUMMARY. California melon (Cucumis melo) growers commonly apply calcium (Ca) fertilizers during fruit development to increase fruit firmness and improve storage life. Drip-irrigated field trials were conducted in central California in 2005 and 2006 to evaluate the efficacy of this practice on honeydew (C. melo Inodorus group) and muskmelon (C. melo Reticulatus group). In the 2005 honeydew trial, three weekly applications of $10 \mathrm{lb} /$ acre $\mathrm{Ca}$ from calcium nitrate $(\mathrm{CN})$, calcium thiosulfate (CTS), or calcium chloride (CC) were injected into the irrigation system during early melon development. In the 2006 muskmelon trial, two applications of $15 \mathrm{lb} /$ acre Ca from CTS or CC were made early, or two applications of CC late, in melon development. The effect of these Ca fertigation treatments on fruit yield, soluble solids concentration, flesh firmness, and Ca concentration were compared with an untreated control receiving no Ca fertigation. Calcium fertigation had no effect on marketable yield, quality, or Ca concentration of honeydew or muskmelon fruit regardless of application timing or Ca source applied. Loss of firmness during either 2 weeks (honeydew) or 1 week (muskmelon) of postharvest storage was unrelated to $\mathrm{Ca}$ fertigation treatment and was not correlated with $\mathrm{Ca}$ concentration in fruit tissue. We conclude that under conditions representative of the California melon industry, Ca fertigation at typical application rates is ineffective in improving honeydew or muskmelon yield or fruit quality.
\end{abstract}

$\mathrm{F}$ ruit firmness and storage life are important melon quality attributes, particularly for the California industry. Melons exported from California to Asian markets must maintain firmness through several weeks of ocean transit. Domestic use of California melons in

Department of Plant Sciences University of California Davis, CA 95616

${ }^{1}$ New Zealand Institute for Crop \& Food Research, Sustainable Production Systems, 265 Lawn Road, RD2, Hastings, 4172, New Zealand

${ }^{2}$ Department of Plant Sciences, University of CaliforniaDavis, Davis, CA 95616

${ }^{3}$ Land, Air and Water Resources Department, University of California-Davis, Davis, CA 95616

${ }^{4}$ Corresponding author. E-mail: johnstonep@crop.cri.nz. "fresh cut" processing is increasing, and fruit firmness is also critical for that use. Premature softening and "glassiness" of melons (a physiological disorder in which fruit flesh appears water-soaked) have been associated with low calcium concentration in the fruit tissue (Lester and Grusak, 1999, 2001; Madrid et al., 2004; Serrano et al., 2002). Calcium $(\mathrm{Ca})$ is thought to play an integral role in stabilizing cell membranes and slowing tissue degradation (Saure, 2005 ). Although the use of postharvest $\mathrm{Ca}$ dips appears to increase $\mathrm{Ca}$ concentration, slow senescence, and maintain fruit firmness of whole melons and cut fruit segments (Lester, 1996; Lester and Grusak, 1999, 2001; Luna-Guzmán and Barrett, 2000; Luna-Guzmán et al., 1999; Saftner et al., 2003), this approach is of limited value where fruit are fieldpacked, as are the majority of California melons.

Ca-mediated disorders such as tipburn of lettuce (Lactuca sativa) (Collier and Tibbitts, 1982) and blossom end rot of tomato (Solanum lycospersicum) (Jones et al., 1991) commonly occur in California, which has created a perception within the industry that soil Ca limitation is widespread. Consequently, Ca amendments and fertilizers are applied to a range of California vegetable crops, including muskmelon and honeydew. However, the ability to reduce Camediated disorders through Ca application under representative field conditions has generally been reported to be poor. Misaghi and Matyac (1981) reported significant suppression of lettuce tipburn by soil application of $\mathrm{Ca}$ in only one of six field trials, and multiple foliar $\mathrm{Ca}$ applications had no effect in any trial. Hartz et al. (2007) found that $\mathrm{Ca}$ fertigation did not increase tissue Ca levels of inner lettuce leaves (those most susceptible to tipburn) nor reduce tipburn severity.

\begin{tabular}{llll}
\hline $\begin{array}{l}\text { Units } \\
\begin{array}{l}\text { To convert U.S. to SI, } \\
\text { multiply by }\end{array}\end{array}$ & U.S unit & SI unit & $\begin{array}{l}\text { To convert SI to U.S., } \\
\text { multiply by }\end{array}$ \\
\hline 0.4047 & acre(s) & $\mathrm{ha}$ & 2.4711 \\
0.1 & $\mathrm{bar}$ & $\mathrm{MPa}$ & 10 \\
9.3540 & gal/acre & $\mathrm{L} \cdot \mathrm{ha}^{-1}$ & 0.1069 \\
2.54 & inch $(\mathrm{es})$ & $\mathrm{cm}$ & 0.3937 \\
25.4 & inch $(\mathrm{es})$ & $\mathrm{mm}$ & 0.0394 \\
0.4536 & $\mathrm{lb}$ & $\mathrm{kg}$ & 2.2046 \\
1.1209 & $\mathrm{~b} / \mathrm{acre}$ & $\mathrm{kg} \cdot \mathrm{ha}^{-1}$ & 0.8922 \\
4.4482 & $\mathrm{lbf}$ & $\mathrm{N}$ & 0.2248 \\
1 & $\mathrm{meq} / \mathrm{L}$ & $\mathrm{mmol}$ charge per liter & 1 \\
28.3495 & $\mathrm{oz}$ & $\mathrm{g}$ & 0.0353 \\
1.1161 & $\mathrm{oz} / \mathrm{inch}$ & $\mathrm{g} \cdot \mathrm{m}^{-1}$ & 0.8960 \\
2.2417 & ton $/ \mathrm{acre}$ & $\mathrm{mg} \cdot \mathrm{ha}^{-1}$ & 0.4461 \\
$\left({ }^{\circ} \mathrm{F}-32\right) \div 1.8$ & $\mathrm{o} F$ & ${ }^{\circ} \mathrm{C}$ & $\left(1.8 \times{ }^{\circ} \mathrm{C}\right)+32$
\end{tabular}


Scott et al. (1993) found that applying Ca at planting (as gypsum) had no effect on Ca concentration of the rind tissue of watermelon (Citrullus lanatus). Similarly, Sundstrom and Carter (1983) found gypsum application to be ineffective in reducing blossom end rot or increasing resistance to fruit cracking in watermelon. Lester and Grusak (2004) reported that multiple foliar $\mathrm{Ca}$ applications increased fruit tissue $\mathrm{Ca}$, improving flesh firmness and storage life of honeydew, but not muskmelon. Only in studies conducted in soilless culture has manipulation of nutrient solution $\mathrm{Ca}$ concentration yielded significant muskmelon fruit quality effects (Bernadac et al., 1996; Madrid et al., 2004; Serrano et al., 2002).

Despite these generally disappointing results, California growers commonly apply soluble Ca fertilizers such as calcium nitrate, calcium thiosulfate, and calcium chloride to melons during fruit development; application through drip irrigation is particularly popular. This study was undertaken to determine whether calcium fertigated through drip irrigation affected fruit yield or quality of honeydew or muskmelon under representative California field conditions.

\section{Materials and methods}

Drip-irrigated field trials were conducted in central California in 2005 and 2006 to evaluate the effects of fertigated $\mathrm{Ca}$ on the yield and fruit quality of honeydew and muskmelon. The 2005 honeydew trial was conducted in Yolo County (lat. $38^{\circ} 32^{\prime} 08.49^{\prime \prime} \mathrm{N}$, long. $121^{\circ} 46^{\prime}$ $57.59^{\prime \prime} \mathrm{W}$ ) on a Yolo silt loam (finesilty, mixed, nonacid, thermic Typic Xerorthents). The 2006 muskmelon trial was conducted in Fresno County (lat. $36^{\circ} 20^{\prime} 24.77^{\prime \prime} \mathrm{N}$, long. $120^{\circ} 06^{\prime}$ 29.04" W) on a Panoche clay loam (fine-loamy, mixed, calcareous, thermic Typic Torriorthents). These sites were representative of soils used for commercial melon production in the Sacramento and San Joaquin Valleys, respectively. Soil cation availability $(0$ to $15 \mathrm{~cm}$ depth) was characterized by saturated paste extraction (Rhoades, 1982). Additionally, a centrifugation method similar to that of Thibault and Sheppard (1992) was used to extract soil solution for cation analysis. In brief, 30-g samples of air-dried soil were placed in polyethylene cylinders and wetted with deionized water to field capacity (defined as the gravimetric water content at a soil moisture tension of $0.02 \mathrm{MPa}$ ). The samples were allowed to equilibrate overnight and were then centrifuged for $40 \mathrm{~min}$ at $2000 \mathrm{rpm}$ equivalent to a force of $\approx 800 g_{n}$. The filtered solutions obtained from both extraction methods were analyzed for $\mathrm{Ca}$, magnesium, potassium, and sodium concentration by atomic emission spectrometry.

Experimental design of both trials was a randomized complete block comparing three $\mathrm{Ca}$ treatments applied through buried drip irrigation lines during fruit growth to a control treatment receiving no $\mathrm{Ca}$ application. Individual plots were one 80 -inch bed wide and $30 \mathrm{~m}$ long replicated either five (2005) or four (2006) times; plant spacing in both years was 12 inches. There was one drip line per bed buried 8 inches deep. In both seasons, irrigation was applied three times per week; irrigation volume was determined by adjusting reference evapotranspiration (Goldhamer and Snyder, 1989) on the basis of crop canopy development. Beginning at early vining, all plots received seven weekly fertigations of a urea:ammonium nitrate blend totaling 135 or $160 \mathrm{~kg} \cdot \mathrm{ha}^{-1} \mathrm{~N}$ in 2005 and 2006, respectively.

In the 2005 honeydew trial, three weekly fertigations with calcium nitrate $(\mathrm{CN})$, calcium thiosulfate $(\mathrm{CTS})$, and calcium chloride (CC) were initiated during early fruit development; this application timing was chosen based on the report of Bernadac et al. (1996) that $\approx 80 \%$ of Ca accumulation in fruit occurs in the first $20 \mathrm{~d}$ after anthesis. Each application delivered $10 \mathrm{lb} /$ acre $\mathrm{Ca}$ at a concentration in the irrigation water of 10 meq/L Ca. To keep $\mathrm{N}$ availability balanced, the $\mathrm{N}$ equivalent contained in the $\mathrm{CN}$ treatment was made up in all other treatments by simultaneous application of ammonium nitrate. In the 2006 muskmelon trial, the CTS and CC treatments were retained, but $\mathrm{CN}$ was replaced with a second $\mathrm{CC}$ treatment (late CC). Late CC fertigation was initiated 1 week after the CTS and CC treatments to more closely approximate current industry practice, in which $\mathrm{Ca}$ is often applied during the final 2 weeks of fruit development. Two weekly fertigations were made for each treatment with each application delivering $15 \mathrm{lb} /$ acre $\mathrm{Ca}$ at a concentration in the water of $20 \mathrm{meq} / \mathrm{L} \mathrm{Ca}$. In both seasons, application rates simulated those used commercially. Irrigation water $\mathrm{Ca}$ was $\approx 1 \mathrm{meq} / \mathrm{L} \mathrm{Ca}$ at both sites. A summary of soil characteristics, $\mathrm{Ca}$ treatments, and production details is provided in Table 1.

In 2005, honeydew fruit were harvested once, and in 2006, muskmelon fruit were harvested nine times over a 2 -week period in keeping with typical commercial practice. Fruit in both seasons were harvested at commercial maturity. For honeydew, this was "Class 2" or riper (Cantwell and Kasmire, 2002); muskmelons were harvested at "slip" stage (when fruit separated cleanly from the vine with pressure). To estimate marketable yield, fruit were sorted according to grade sizes $(8,6,5$, and 4 in honeydew and $18,15,12$, and 9 in muskmelon). Grade sizes reflected the number of fruit required to fill standard cartons holding 30 or $40 \mathrm{lb}$ of honeydew and muskmelon, respectively.

In each season, 16 medium-sized fruit (honeydew of size 5 or 6 at class 2 maturity, muskmelon of size 12 or 15) were collected from each plot to evaluate fruit quality. Half of the fruit was evaluated on the day of harvest, and half was stored for either 2 weeks at $7{ }^{\circ} \mathrm{C}$ (honeydew) or 1 week at $4{ }^{\circ} \mathrm{C}$ (muskmelon) before evaluation. After this period of storage, fruit were returned to ambient room temperature $\left(21^{\circ} \mathrm{C}\right)$ overnight before quality determinations were made. Flesh firmness and soluble solids concentration (SSC) of each fruit were determined; Ca concentration of fruit was measured at harvest only. From each fruit, an equatorial slice of $\approx 3 \mathrm{~cm}$ wide was collected, and all measurements were made on middle mesocarp tissue midway between the ground spot and the top of the fruit. Firmness was determined using a manually operated penetrometer (Western Industrial Supply, San Francisco, CA); there were four measurements per fruit. The instrument recorded the pressure required to push a $0.5-\mathrm{cm}$ wide rounded probe $1 \mathrm{~cm}$ deep into the flesh. A juice sample from this same region was evaluated for SSC using a temperature-compensated 
refractometer (Atago, Tokyo). During the evaluation at harvest, a composite flesh sample from all eight fruit per treatment was collected, dried at $65{ }^{\circ} \mathrm{C}$, and ground to pass a $\mathrm{l}-\mathrm{mm}$ screen. Fruit $\mathrm{Ca}$ concentration was determined by inductively coupled plasma-atomic emission spectroscopy after nitric acid/hydrogen peroxide microwave digestion (Sah and Miller, 1992).

\section{Results}

Calcium fertigation during fruit growth had no significant effect on marketable yield or fruit number of either honeydew or muskmelon (Table 2). Across treatments, marketable yield of honeydew and muskmelon averaged 3231 and 3078 cartons/ha, respectively; mean industry yields were $\approx 1800$ and 1600 cartons/ha, respectively. Such high yields reflected the value of buried drip irrigation in minimizing water stress and keeping the soil surface dry to prevent fruit rot and ground spots.

Similarly, there was no significant effect of Ca fertigation on fruit quality either at harvest or after storage. Across treatments at harvest fruit SSC averaged $11.8 \%$ and $10.9 \%$ and

Table 1. Soil fertility characteristics, melon cultivar, sowing date, calcium (Ca) treatments, and harvest initiation details for the honeydew and muskmelon trials in 2005 to 2006 .

\begin{tabular}{|c|c|c|}
\hline & $\begin{array}{l}2005 \text { Honeydew } \\
\text { trial }\end{array}$ & $\begin{array}{c}2006 \text { Muskmelon } \\
\text { trial }\end{array}$ \\
\hline \multicolumn{3}{|l|}{ Soil fertility characteristics } \\
\hline Soil pH & 7.2 & 7.7 \\
\hline \multicolumn{3}{|l|}{ Saturated paste Ca } \\
\hline$(\mathrm{meq} / \mathrm{L})^{\mathrm{z}}$ & 2.1 & 3.0 \\
\hline [\% cations (milliequivalent basis)] & 24 & 40 \\
\hline \multicolumn{3}{|l|}{ Soil solution $\mathrm{Ca}$ (centrifuge method) } \\
\hline$(\mathrm{meq} / \mathrm{L})$ & 13.1 & 12.3 \\
\hline [\% cations (milliequivalent basis)] & 29 & 54 \\
\hline Cultivar & Greenflesh & Oro Rico \\
\hline Sowing date & 1 June & 20 Apr. \\
\hline Ca treatments ${ }^{y}$ & $\mathrm{CN}, \mathrm{CTS}, \mathrm{CC}$ & $\begin{array}{l}\text { Early CTS, early CC, } \\
\text { late } \mathrm{CC}^{\mathrm{x}}\end{array}$ \\
\hline Ca fertigations (no.) & 3 & 2 \\
\hline Ca fertigation date(s) & 26 July, 2 and 9 Aug. & 22 and 29 June, 6 July \\
\hline Harvest initiation & 25 Aug. & 12 July \\
\hline
\end{tabular}

${ }^{\mathrm{z}} 1 \mathrm{meq} / \mathrm{L}=1 \mathrm{mmol}$ charge per liter.

${ }^{y} \mathrm{CN}=$ calcium nitrate; $\mathrm{CTS}=$ calcium thiosulfate $; \mathrm{CC}=$ calcium chloride

${ }^{x}$ Early treatments applied at two earliest dates; late treatment applied at last two dates. fruit firmness averaged 39 and $18 \mathrm{~N}$ in honeydew and muskmelon, respectively. A factor in the difference in firmness between the melon types was maturity status at harvest ["slip" stage for the muskmelon compared with maturity Stage 2 ("mature, ripening") for the honeydew]. Fruit firmness declined during storage; this decline was greater in muskmelon $(50 \%)$ than in honeydew $(25 \%)$ despite the shorter storage period, again reflecting the more mature state at harvest. Loss of firmness was unrelated to $\mathrm{Ca}$ treatment and was not significantly correlated with Ca concentration in fruit tissue (Fig. 1). Calcium fertigation failed to significantly increase $\mathrm{Ca}$ concentration in fruit tissue in either trial. Across treatments, fruit $\mathrm{Ca}$ concentration averaged $0.041 \%$ in honeydew and $0.080 \%$ in muskmelon. In neither trial was "glassiness" of fruit tissue observed in any treatment either at harvest or after storage.

\section{Discussion}

Calcium fertigation during fruit development had no effect on marketable yield, quality, or Ca concentration of honeydew or muskmelon fruit, regardless of application timing or Ca source. These results can be explained by the relatively high soil $\mathrm{Ca}$ availability at these sites and by the physiological limitation of $\mathrm{Ca}$ movement into fruit tissue. Soil solution $\mathrm{Ca}$ was 13 and $12 \mathrm{meq} / \mathrm{L}$ at the 2005 and 2006 sites,

Table 2. Effect of calcium (Ca) fertigation on marketable yield and fruit quality in honeydew and muskmelon in 2005 to 2006 .

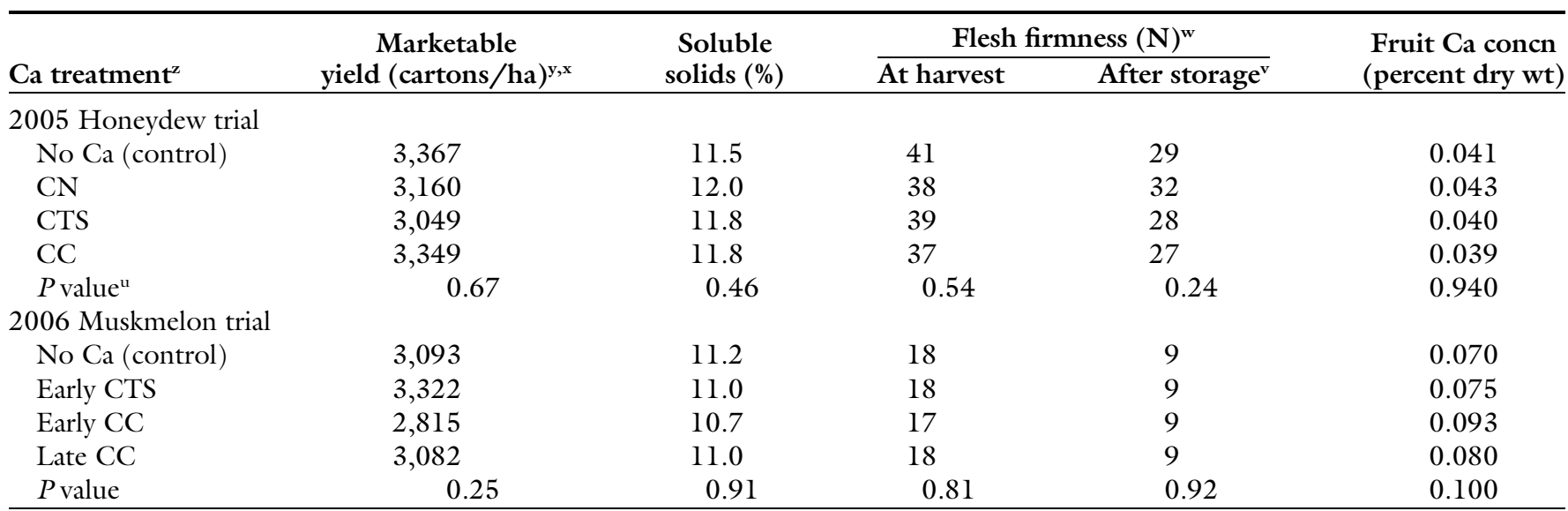

${ }^{2} \mathrm{CN}=$ calcium nitrate; $\mathrm{CTS}=$ calcium thiosulfate; $\mathrm{CC}=$ calcium chloride.

y Approximately $30 \mathrm{lb}[13.6 \mathrm{~kg}$ (honeydew)] or $40 \mathrm{lb}[18.1 \mathrm{~kg}$ (muskmelon)] per carton.

${ }^{\mathrm{x}} 1$ carton/ha $=0.4047$ carton/acre.

w $1 \mathrm{~N}=0.2248 \mathrm{lbf}$

v Determined after either 2 weeks storage at $7^{\circ} \mathrm{C}\left[44.6^{\circ} \mathrm{F}\right.$ (honeydew)] or l-week storage at $4{ }^{\circ} \mathrm{C}\left[39.2{ }^{\circ} \mathrm{F}\right.$ (muskmelon) $]$

${ }^{\mathrm{D}} P>0.05$ are nonsignificant. 

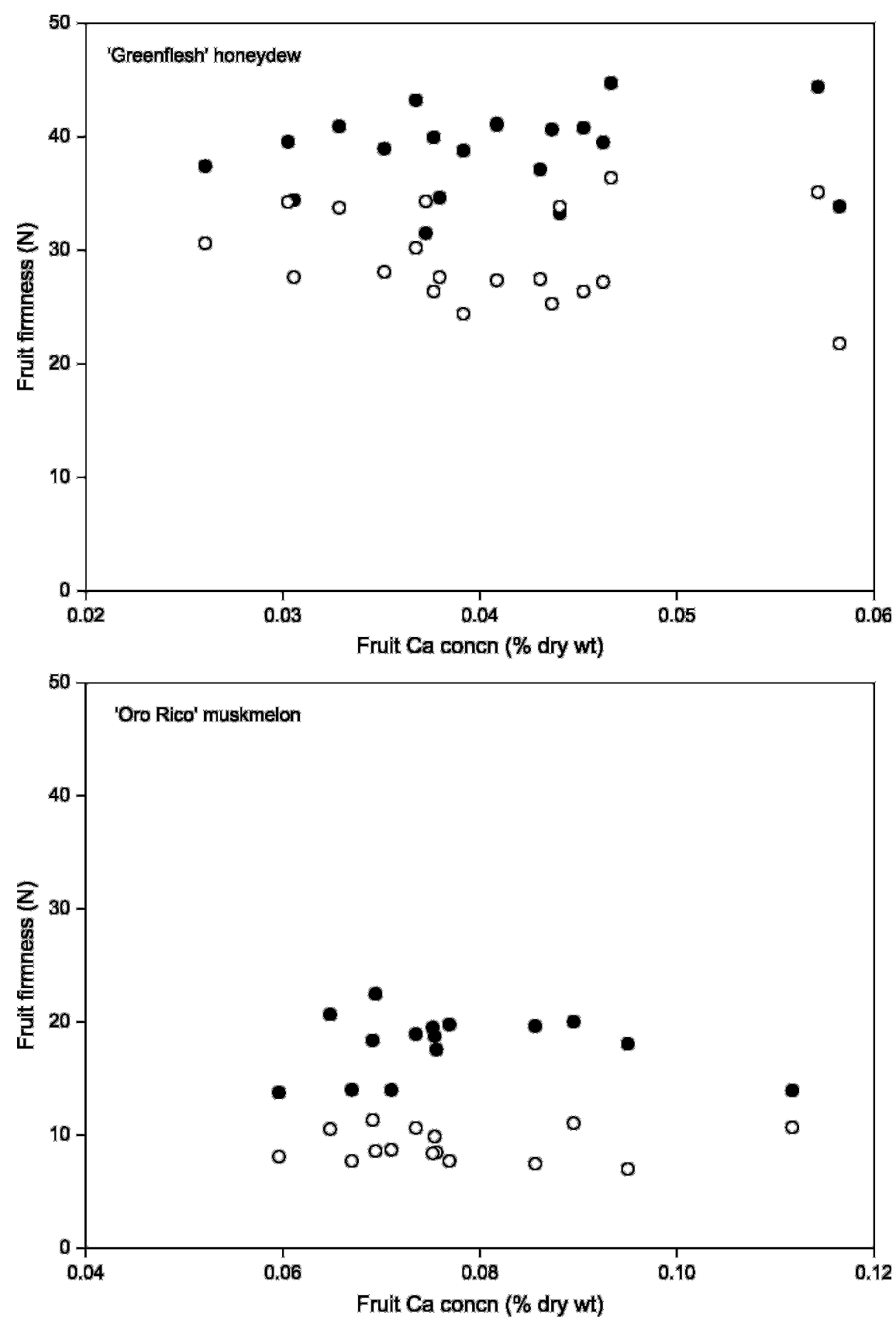

Fig. 1. Relationship between fruit calcium (Ca) concentration (\% dry weight) and fruit flesh firmness at harvest $(\bullet)$ and after storage $(\bigcirc)$ in 'Greenflesh' honeydew and 'Oro Rico' muskmelon in 2005 to 2006 ( $1 \mathrm{~N}=0.2248 \mathrm{lbf}$ ).

respectively; at a field capacity moisture content of $\approx 25 \%$ (wt/wt) and typical field bulk density (1.3 $\left.\mathrm{g} \cdot \mathrm{cm}^{-3}\right)$, these fields had greater than $200 \mathrm{~kg} \cdot \mathrm{ha}^{-1} \mathrm{Ca}$ in soil solution in the top $30 \mathrm{~cm}$ of soil. Each fertigation of 10 to $15 \mathrm{lb} /$ acre $\mathrm{Ca}(\approx 11$ to 17 $\left.\mathrm{kg} \cdot \mathrm{ha}^{-1}\right) \mathrm{Ca}$ represented a minimal change in soil $\mathrm{Ca}$ availability. Furthermore, these fields had relatively modest soil Ca levels compared with the regional norm. Hartz et al. (2007) reported that soil solution $\mathrm{Ca}$ of a group of 20 representative central California soils averaged 34 $\mathrm{meq} / \mathrm{L} \mathrm{Ca}$, representing $57 \%$ of cation charges. The much lower fruit Ca concentration in the 2005 trial undoubtedly reflected cation competition at that site (Ca represented only $29 \%$ of cation charges in the soil solution compared with $54 \%$ at the 2006 site).

The Ca treatments used in these experiments were designed to reflect current industry practices with regard to Ca source, rate, and application timing. Application rates of these soluble Ca fertilizers high enough to substantially increase soil Ca availability would be prohibitively expensive and in the case of calcium nitrate would result in excessive $\mathrm{N}$ availability. For high rates of $\mathrm{Ca}$ application, the only realistic options are lime and gypsum. However, prior research suggests that even high rates of these amendments have minimal effect on melon quality or Ca status under field conditions (Scott et al., 1993; Sundstrom and Carter, 1983). In neither study did gypsum application increase fruit yield or SSC. Even with application rates exceeding $\mathrm{l} \mathrm{mg} \cdot \mathrm{ha}^{-1}$, Scott et al. (1993) found no significant increase in Ca concentration in rind tissue of watermelon fruit, whereas Sundstrom and Carter (1983) reported no change in watermelon rind thickness or resistance to cracking.

These results underscored the difficulty of enhancing Ca supply to fruit. Calcium moves primarily in xylem and accumulates in actively transpiring tissues (Clarkson, 1984). Calcium mobility in phloem is extremely limited (Hanger, 1979). In muskmelon, $80 \%$ of fruit $\mathrm{Ca}$ was accumulated in the first $20 \mathrm{~d}$ after anthesis, the time when xylem flow to fruit is significant; once transport by phloem predominated, additional Ca import was minimal (Bernadac et al., 1996). Working in a hydroponic system, Madrid et al. (2004) found that even with adequate $\mathrm{Ca}$ supply (8 $\mathrm{meq} / \mathrm{L}$ ), environmental factors resulting in low transpiration increased the incidence of glassiness in melon.

The results of Lester and Grusak (2004) confirmed the limitation of $\mathrm{Ca}$ movement into melon fruit through phloem and demonstrated the practical limitation of foliar $\mathrm{Ca}$ application to influence melon quality. Four foliar $\mathrm{Ca}$ sprays during melon development increased firmness and $\mathrm{Ca}$ concentration in honeydew, but not muskmelon. Because there is no reason to suspect that such closely related melon types differ in their ability to translocate Ca from leaves to fruit through phloem, the improvement in honeydew quality and fruit $\mathrm{Ca}$ concentration must reflect absorption of $\mathrm{Ca}$ deposited directly on the fruit. The netted epidermis of muskmelon was apparently a barrier to direct $\mathrm{Ca}$ absorption. This not only suggested that foliar $\mathrm{Ca}$ 
application is of limited value as a tool to improve muskmelon quality, but also emphasized that for foliar sprays to be effective on honeydew, they must be applied in a manner to maximize direct fruit coverage. The application volume used by Lester and Grusak was 75 to $114 \mathrm{~L} \cdot \mathrm{ha}^{-1}$, which precludes aerial application, the predominate method of chemical application in the California melon industry.

Given the limitations of foliar and soil $\mathrm{Ca}$ application, the commercial industry will need to use other approaches to improve melon quality and storage life. Those approaches include cultivar selection and postharvest $\mathrm{Ca}$ treatment. Fruit firmness varies substantially among commercial cultivars (Evensen, 1983; Portela and Cantwell, 1998). Postharvest $\mathrm{Ca}$ dip treatment of whole fruit (Lester and Grusak, 1999, 2001) or cut fruit (Luna-Guzmán and Barrett, 2000; Luna-Guzmán et al., 1999; Saftner et al., 2003) has shown considerable promise. Such treatment can more than double flesh Ca concentrations (Luna-Guzmán et al., 1999) and storage life (Lester and Grusak, 1999). However, postharvest dip treatment is not an option for growers who field-pack fruit.

We conclude that under conditions representative of the California melon industry, Ca fertigation, regardless of $\mathrm{Ca}$ source or application timing, is ineffective in improving honeydew or muskmelon yield or fruit quality. Cultivar selection and postharvest $\mathrm{Ca}$ treatment are more promising approaches to obtaining firmer fruit and extended storage life.

\section{Literature cited}

Bernadac, A., I. Jean-Baptiste, G. Bertoni, and P. Morand. 1996. Changes in calcium contents during melon (Cucumis melo L.) fruit development. Scientia Hort. 66: 181-189.

Cantwell, M.I. and R.F. Kasmire. 2002. Postharvest handling systems: Fruit vegetables, p. 407-421. In: Kader, A.A. (ed.). Postharvest technology of horticultural crops. 3rd Ed. Univ. California, Div. Agr. Natural Resources Publ. 3311.
Clarkson, D.T. 1984. Calcium transport between tissues and its distribution in the plant. Plant Cell Environ. 7:449-456.

Collier, G.F. and T.W. Tibbitts. 1982. Tipburn of lettuce. Hort. Rev. (Amer. Soc. Hort. Sci.) 4:49-65.

Evensen, K.B. 1983. Effects of maturity at harvest, storage temperature, and cultivar on muskmelon quality. HortScience 18:907-908.

Goldhamer, D.A. and R.L. Snyder. 1989. Irrigation scheduling: A guide for efficient on-farm water management. Univ. California Coop. Ext. Bul. 21454.

Hanger, B.C. 1979. The movement of calcium in plants. Commun. Soil Sci. Plant Anal. 10:171-193.

Hartz, T.K., P.R. Johnstone, R.F. Smith, and M.D. Cahn. 2007. Soil calcium status unrelated to tipburn of romaine lettuce in California. HortScience 42:1681-1684.

Jones, J.B., J.P. Jones, R.E. Stall, and T.A. Zitter. 1991. Compendium of tomato diseases. APS Press, St. Paul, MN.

Lester, G. 1996. Calcium alters senescence rate of postharvest muskmelon fruit disks. Postharvest Biol. Technol. 7:91-96.

Lester, G.E. and M.A. Grusak. 1999. Postharvest application of calcium and magnesium to honeydew and netted muskmelons: Effects on tissue ion concentrations, quality, and senescence. J. Amer. Soc. Hort. Sci. 124:545-552.

Lester, G.E. and M.A. Grusak. 2001. Postharvest application of chelated and nonchelated calcium dip treatments to commercially grown honeydew melons: Effects on peel attributes, tissue calcium concentration, quality and consumer preference following storage. HortTechnology 11:561-566.

Lester, G.E. and M.A. Grusak. 2004. Field application of chelated calcium: Postharvest effects on muskmelon and honeydew fruit quality. HortTechnology 14:29-38.

Luna-Guzmán, I. and D.M. Barrett. 2000. Comparison of calcium chloride and calcium lactate effectiveness in maintaining shelf stability and quality of fresh-cut muskmelons. Postharvest Biol. Technol. 19:61-72.

Luna-Guzmán, I., M. Cantwell, and D.M. Barrett. 1999. Fresh-cut muskmelon: Effects of $\mathrm{CaCl}_{2}$ dips and heat treatments on firmness and metabolic activity. Postharvest Biol. Technol. 17: 201-213.

Madrid, R., M. Valverde, V. Alcolea, and F. Romojaro. 2004. Influence of calcium nutrition on water soaking disorder of ripening muskmelon melon. Scientia Hort. 101:69-79.

Misaghi, I.J. and C.A. Matyac. 1981. Soil and foliar applications of calcium chloride and calcium nitrate to control tipburn of head lettuce. Plant Dis. 65:821-822.

Portela, S.I. and M.I. Cantwell. 1998. Quality changes of minimally processed honeydew melons stored in air or controlled atmospheres. Postharvest Biol. Technol. 14:351-357.

Rhoades, J.D. 1982. Soluble salts, p. 167-179. In: Page, A.L. (ed.). Methods of soil analysis, Part 2: Chemical and microbiological properties. Monogr. No. 9. Amer. Soc. Agron., Madison, WI.

Saftner, R.A., J. Bai, J.A. Abbott, and Y.S. Lee. 2003. Sanitary dips with calcium propionate, calcium chloride, or a calcium amino acid chelate maintain quality and shelf stability of fresh-cut honeydew chunks. Postharvest Biol. Technol. 29: 257-269.

Sah, R.N. and R.O. Miller. 1992. Spontaneous reaction for acid dissolution of biological tissues in closed vessels. Anal. Chem. 64:230-233.

Saure, M.C. 2005. Calcium translocation in fleshy fruit: Its mechanism and endogenous control. Scientia Hort. 105:65-89.

Scott, W.D., B.D. McCraw, J.E. Motes, and M.W. Smith. 1993. Application of calcium to soil and cultivar affect elemental concentration of watermelon leaf and rind tissue. J. Amer. Soc. Hort. Sci. 118:201-206.

Serrano, M., A. Amoros, M.T. Pretel, M.C. Martinez-Madrid, R. Madrid, and F. Romojaro. 2002. Effect of calcium deficiency on melon (Cucumis melo L.) texture and glassiness incidence during ripening. Food Sci. Technol. 8:147154.

Sundstrom, F.J. and S.J. Carter. 1983. Influence of $\mathrm{K}$ and $\mathrm{Ca}$ on quality and yield of watermelon. J. Amer. Soc. Hort. Sci. 108:879-881.

Thibault, D.H. and M.I. Sheppard. 1992. A disposable system for soil pore-water extraction by centrifugation. Commun. Soil Sci. Plant Anal. 23:1629-1641. 